\title{
Overinvestment of Free Cash Flow and Manager's Overconfidence
}

\author{
El Gaied Moez ${ }^{1} \&$ Zgarni Amina $^{2}$ \\ ${ }^{1}$ Assistant in Accounting, Higher Institute of Finance and Taxation of Sousse, Tunisia \\ ${ }^{2}$ Doctor in Finance, Faculty of Economics and Management of Tunis, Tunisia \\ Correspondence: El Gaied Moez, Higher Institute of Finance and Taxation of Sousse, Tunisia.
}

Received: December 7, 2017

Accepted: January 15, 2018

Online Published: February 2, 2018

doi:10.5539/ibr.v11n3p48

URL: https://doi.org/10.5539/ibr.v11n3p48

\begin{abstract}
The problem of over-investment of free cash flows has been heavily debated in the financial literature of companies. However, only a handful of studies have examined this problem in the context of behavioral finance. The objective of this article is to study the effect of the manager's overconfidence on the over-investment of the free cash flows. We construct a proxy measure of overconfidence and we use Richardson's model to measure over-investment expenditure. Our empirical study was conducted on a sample of 150 US companies and for a period from 1995 to 2012. Our results show a positive and significant relationship between over-investment and free cash flows. Also, we find the positive relationship is greater when managers are highly confident. The results generated by this study confirm that investment distortions are associated with behavioral attributes or biases.
\end{abstract}

Keywords: over-investment, overconfidence, free cash flow, behavioral finance

\section{Introduction}

The over-investment hypothesis of free cash flows has been mostly debated in the financial literature. Many explanations have been put forward to apprehend this problem which can harm the shareholders. In this respect, it seems relevant to point out that the hypothesis of managerial discretion seems to constitute a first explanation of the positive relationship between over-investment and free cash flows. Blanchard et al. (1994) show with a sample of eleven firms with substantial free cash flows, that managers reveal opportunistic behavior and, as a result, engage in investment projects that are destructive of value. This thesis has been validated by Richardson (2006) and Zhang et al. (2016), who establish that the presence of free cash flows generates a harmful effect. In fact, according to the predictions of the hypothesis of managerial discretion, they conclude that the managers of the companies secreting free cash-flows and presenting weak opportunities of growth, choose to invest in projects with negative NPV and to maximize their own interests in the detriment of those of shareholders.

The decision to over-invest is not always the consequence of the managers' opportunism, it can emanate from a purely irrational behavior. A behavior that can be integrated in the framework of managers' models of overconfidence, and more precisely in the behavioral finance approach. In fact, managers' models of overconfidence suggest that managers suffer from certain behavioral biases that may lead them to make a wrong investment decision and consequently move away from the optimal level of investment.

The behavioral finance approach seems to be as a realistic description of the problem of over-investment. This behavioral approach was advanced by Roll (1986), who relaxes the assumption of full rationality of the managers and looks rather on their irrational side. For Roll (1986), managers who acquire companies tend to overpay their targets because they tend to overestimate their management skills for new entities purchased. Hayward \& Hambrick (1997), Brown \& Sarma (2007), Ye \& Yuan (2008) and Malmendier \& Tate (2008), support the idea that overconfidence, pride and arrogance of managers lead them to overestimate the gains from synergies and pay an excessive premium to the target company. Heaton (2002) shows that the overconfidence of managers gives rise not only to a problem of over-investment, but also to several models of liquidity constraints associated with expensive external financing. Huang et al. (2011) establish that cash flow is the best source of funding for highly confident managers and that investment distortion due to overconfidence can be mitigated by reducing agency costs through good governance. Xiao \& Zhou (2017) argue that overconfidence cannot be considered as a good investment strategy for the company. Indeed, they believe that managers' overconfidence is tributary on any increase in over-investment expenditure. 
The objective of this study is to test the effect of overconfidence on the sensitivity of over-investment to free cash flows. Our study contributes to research in behavioral finance and suggests that the behavioral biases of managers can affect the investment policy of companies. Unlike Richardson (2006) and Chen et al. (2016) who are interested in the simple relationship between free cash flows and over-investment, our study tests the combined effect of free cash flows and manager's overconfidence on over-investment expenditure. To carry out our analysis, we will proceed in two steps. The first step is to measure, according to the GMM system dynamic panel method, and more precisely the Blundell \& Bond estimator (1998), over-investment expenditure like Richardson (2006). Then, in the second step, we will develop our second model. More specifically, we will use a proxy as a measure of overconfidence and test its combined impact with free cash flows on over-investment expenditure.

The rest of the article is organized as follows. Section two presents the review of the literature and research hypotheses. Section three develops our sample and displays the selected research methodology. Section four shows our main empirical results, and Section five presents our conclusion.

\section{Literature Review and Hypotheses Development}

Several prior studies hypothesize a positive relationship between over-investment and free cash flows. Richardson (2006), who reconciles the results of Blanchard et al. (1994), Kallapur (1994) and Bates (2005), find that high free cash flow firms over-invest $20 \%$ of each additional dollar of positive free cash flows. Miguel \&Pindado (2001), Mcmahon (2003) and Tang et al. (2007) prove that firms with high free cash flow tend to over-invest. Zhang (2007) find, through a survey, that $18.92 \%$ of free cash flows were used to over-invest. Mueller \&Peev (2007) and Chen \& Liao (2012) show that the hypothesis of managerial discretion remains valid in the Asian context. These authors have shown through an empirical validation of a sample of Chinese firms that the presence of free cash flows offers managers the opportunity to invest in negative NPV projects. Chen, Sun \& Xu (2016) examine whether and to what extent the characteristics of free cash flows and governance affect the level of investment of Chinese companies. In line with the hypothesis of managerial discretion, it turns out that over-investment expenditure increases with current free cash flows and that it is more assertive for companies with positive free cash flows. Therefore, our first hypothesis is as follows:

Hypothesis 1: firms with free cashflows are able to over-invest.

We assume in accordance with Richardson (2006) that this hypothesis is only true for firms with positive free cash flows. This may be justified by the fact that firms that generate negative free cash flows use capital markets to finance themselves, which is, in itself a control mechanism that reduces the risk of over-investment. Otherwise, it is pertinent to point out the idea, commonly accepted by theoreticians and practitioners, that behavioral finance helps explain investment decisions. In addition to the assumption of managerial discretion, behavioral finance gives us the manager's overconfidence as a second explanation for the problem of over-investment. This assent has been the subject of a great deal of theoretical and empirical research. Several studies, led mainly by Hayward \& Hambrick (1997), Heaton (2002), Lin et al. (2005), Malmendier \& Tate (2008) and very recently by Wang, Chen, Chen \& Huang (2016), contribute to the discernment of behavioral biases that affect investment decisions made by managers. More specifically, these studies are based on the intuition that managers, whose confidence is excessive, tend to overestimate their skills, their decisions, as well as the expected income from investments. All things equal otherwise, they assume that the excessively confident managers can undertake negative NPV projects. Grundy \& Li (2010) state that the behavioral bias of the manager can frame and influence the current and strategic decisions of the firm. They refer to the idea that the higher the level of managerial optimism, the higher the investment expenditure. This last result gives presumptions that the optimistic manager can undertake unprofitable investments. Ahmed \&Duellman (2013) and Hribar \& Yang (2015) favorably share this juncture and agree that overly confident managers overestimate the return on investment projects. Ben-David, Graham \& Harvey (2013) and Hirshleifer, Teoh \& Low (2012), show how individual biases affect investment decisions and investment efficiency. Chen \& Lin (2012) show that companies with very optimistic managers will invest more than companies with less optimistic managers. Recently, Xiao \& Zhou (2017) show strong evidence that overconfidence is a step towards over-investing free cash flows. Thus, by positioning itself on the side of predictions of behavioral finance, it is expected that manager's overconfidence could lead to the over-investment of free cash flows. Our second hypothesis would therefore be the following:

\section{Hypothesis 2: Overconfidence of manager increases the overinvestment of free cash flows.}

This hypothesis, which makes it possible to identify the contribution of behavioral finance to explain over-investment expenditure, is our contribution compared to previous studies of Richardson (2006) and Chen et al. (2009), who is dealing with a simple way the positive relationship between over-investment and free cash flow. Contrary to these studies, we will test if the managers' excess confidence governs the positive relationship between 
free cash flows and over-investment expenditure. The idea behind this test is that, in the presence of excessively confident managers with substantial free cash flows, the risk of overinvestment becomes more distinguished.

\section{Research Methodology}

To measure over-investment expenditure, we will use Richardson's model (2006). In his study, Bergstresser (2006) argues that the study of Richardson (2006) is one of the works that have significantly contributed to improve the test of over-investment of free cash flows. Its contribution stems mainly from its model of expected investment expenditure. The model is as follows:

$$
\begin{aligned}
I_{N E W i, t}= & \alpha+\beta_{1} \text { Growt }_{i, t-1}+\beta_{2} \text { Leverage }_{i, t-1}+\beta_{3} \text { Cash }_{i, t-1}+\beta_{4} \text { Age }_{i, t-1}+ \\
& \beta_{5} \text { Size }_{i, t-1}+\beta_{6} \text { Stock Returns }_{i, t-1}+\beta_{7} I_{N E W i, t-1}+\varepsilon_{i, t}
\end{aligned}
$$

With $: I_{\text {Total }}=I_{\text {Maintenance }}+I_{N E W}$

And $: I_{N E W}=I_{N E W}^{*}+I_{N E W}^{\varepsilon}$

Where $\mathrm{I}_{\mathrm{NEW}}$ is the investment expenditure on new projects, $\mathrm{I}_{\mathrm{NEW}}^{*}$ is the expected investment on new projects, $\mathrm{I}_{\text {Total }}$ is the total investment expenditure, $\mathrm{I}_{\text {Maintenance }}$ is the maintenance investment expenditure, $\mathrm{I}_{\mathrm{NEW}}^{\varepsilon}$ is the over-investment in new projects, Growth is the growth rate of sales which measure growth opportunity, Leverage is the firm's leverage, Cash is the liquidity level, Age measures the age of the firm, Size is the firm's size, Stock Returns is the yield.

\begin{tabular}{|c|c|c|}
\hline Variable & Definition & Measure \\
\hline $\mathrm{I}_{\text {NEW }}$ & $\begin{array}{l}\text { Investment expenditure on new } \\
\text { projects }\end{array}$ & $\begin{array}{l}\text { The difference between total investment }\left(\mathrm{I}_{\text {Total }}\right) \\
\text { and asset maintenance investment }\left(\mathrm{I}_{\text {Maintenance }}\right) \text {, } \\
\text { scaled by to total assets. }\end{array}$ \\
\hline Growth & Growth opportunity & $\begin{array}{l}\text { Growth rate of sales, proxy for investment } \\
\text { opportunity. }\end{array}$ \\
\hline Leverage & Leverage & $\begin{array}{l}\text { The ratio of the sum of the book value of short } \\
\text { term and long term debt to total assets. }\end{array}$ \\
\hline Cash & Liquidity level & $\begin{array}{l}\text { The balance of cash and short term investments } \\
\text { to total assets. }\end{array}$ \\
\hline Age & Age of the firm & $\begin{array}{l}\text { The log of the number of years the firm has been } \\
\text { established. }\end{array}$ \\
\hline Size & Size of the firm & $\begin{array}{l}\text { The log of the total assets measured at the start of } \\
\text { the year. }\end{array}$ \\
\hline Stock Returns & Stock returns & $\begin{array}{l}\text { The stock returns for the year prior to the } \\
\text { investment year. It is measured as the change in } \\
\text { market value of the firm over that prior year. }\end{array}$ \\
\hline $\mathrm{I}_{\text {Total }}$ & Total investment expenditure & $\begin{array}{l}\text { The sum of all outlays on capital expenditure, } \\
\text { acquisitions and research and development less } \\
\text { receipts from the sale of property, plant and } \\
\text { equipment }\end{array}$ \\
\hline $\mathrm{I}_{\text {Maintenance }}$ & Maintenance investment expenditure & $\begin{array}{l}\text { The investment expenditure necessary to } \\
\text { maintain assets in place. The proxy for } \\
\text { ( } \mathrm{I}_{\text {Maintenance }} \text { ) is amortization and depreciation. }\end{array}$ \\
\hline $\mathrm{I}_{\mathrm{NEW}}^{*}$ & $\begin{array}{l}\text { An estimate of the expected level of } \\
\text { new investment. }\end{array}$ & The fitted value from the model 1 . \\
\hline $\mathrm{I}_{\mathrm{NEW}}^{\varepsilon}$ & An estimate of over-investment & Over-investment is the residual from the model 1. \\
\hline
\end{tabular}

Table 1. Measures of variables

The contribution of this first model is that it allows shareholders to detect the extent of the over-investment problem of free cash flows. Once present, this problem of over-investment could harm the shareholders enormously, who in turn will try to establish and / or at least review the set of control mechanisms of managers. Estimated over-investment expenditure ( $\left.\mathrm{I}_{\mathrm{NEW}}^{\varepsilon}\right)$ are expressed as the difference between the level of investment expenditure on new projects $\left(\mathrm{I}_{\mathrm{NEW}}\right)$ and the level of expected investment on new projects $\left(\mathrm{I}_{\mathrm{NEW}}^{*}\right)$. From an empirical point of view, the level of over-investment of the firm is measured by the residuals of the regression of the first model. The positive residual represents over-investment, and the negative residual under-investment. Our study focuses on over-investment, so we choose only observations with positive residuals.

After measuring over-investment, it will be our purpose, in a second step, to test the relationship between over-investment and free cash flows. To do this, we will use the following model which owes much to Richardson (2006).

$$
I_{N E W i, t}^{\varepsilon}=\alpha+\delta_{1} F C F_{i, t}<0_{t}+\delta_{2} F C F_{i, t}>0_{t}+\varepsilon_{i, t}
$$

However, to test the impact of manager's overconfidence on over-investment expenditure, in a third step, and 
unlike Richardson (2006), who focuses only on the sensitivity of over-investment to free cash flows, we will introduce an interaction variable that also captures the effect of overconfidence.

$$
I_{N E W i, t}^{\varepsilon}=\alpha+\beta_{1} F C F_{i, t} * E C<0_{t}+\beta_{2} F C F_{i, t} * E C>0_{t}+\varepsilon_{i, t}
$$

Where, INEW are estimated over-investment expenditure, FCF is a firm's free cash flow and EC is the degree of manager overconfidence.

Before embarking on econometric and economic interpretations of the results obtained, it seems useful to specify the measure of degree of overconfidence that has been retained in this research. In this regard, the review of the literature on behavioral finance highlights a multitude of measures. For Malmendier \& Tate (2005), the manger's overconfidence can be judged either by his beliefs or by descriptions made by third parties. In the same vein, Hayward \& Hambrick (1997) established four indices of overconfidence: recent stock market performance, recent press releases of managers, manager's compensation, and the composite factor of these three indices. Wang, Zhang \& Yu (2010) choose the difference between manager's predicted profit and real profit as a proxy of manager's overconfidence. In our study, we construct a proxy composed of both the executive's compensation and his decision-making power. The latter being measured by the inverse of the number of managers composing the management team. All things equal otherwise, the lower the number of managers, the greater the decision-making power of the manager. This second component of our chosen proxy, decision-making power, draws its logic from the fact that it gives the manager the feeling of being the most important and the first decision-maker, which may lead him to overestimate his abilities and skills.

Regarding the FCF, we have retained Richardson's measure (2006). Closer to the conception defended by Jensen (1986), Yong, Dao \& Haiyue (2015) and Guarglia \& Yang (2016), this measure of free cash flow is as follows:

Table 2. Measure of Free cash flow

\begin{tabular}{lc}
\hline Sources & Acronym \\
\hline Free cash flow from Existing Assets in Place & $\mathrm{CF}_{\mathrm{A} / \mathrm{P}}$ \\
+ Net Cash flow from Operating Activities & $\mathrm{CFO}$ \\
- Maintenance Investment Expenditure & $\mathrm{I}_{\mathrm{MAINTENANCE}}$ \\
+ Research and Development Expenditure & $\mathrm{RD}$ \\
& $\mathrm{I}_{\mathrm{NEW}}^{*}$ \\
Free cash flow from Growth Opportunities &
\end{tabular}

Net Free cash flow

$\mathrm{FCF}=\mathrm{CF}_{\mathrm{A} / \mathrm{P}}-\mathrm{I}_{\mathrm{NEW}}^{*}$

Finally, to control the size effect, the free cash flows thus obtained would be scaled by the book value of the total assets.

\section{Empirical Results}

\subsection{Sample Selection and Statistical Description}

The empirical study focuses on a sample of American companies listed over a period of eighteen years ranging from 1995 to the year 2012. These companies belong to various sectors of activity: food industry, chemical industry, trade ... From our initial sample, we excluded firms with missing financial data. We have also dismissed companies in the financial sector, including banks, insurance companies, investment companies ... This choice can be justified by three main reasons. First, these companies belong to a highly regulated financial sector, which is covered by a special regime. Secondly, because regulation could reduces manager's discretion, this seems to distance us from our research objective in this study, which is essentially to test the impact of overconfidence on the overinvestment of free cash flows. Thirdly, we consider that taking financial institutions into account leads to the result that the observations would be more heterogeneous which could ultimately lead to biased empirical results. Finally, we note that the only consideration for listed firms stems from the idea that these firms follow information disclosures, considered to be voluntary and more reliable.

Finally, we obtained a sample of 150 companies observed over a period of 18 years. The financial and accounting information for these companies is extracted from the "Compustat" database. The presentation of the distribution of the sample according to the sectors of activity shows that the firms belong to five different sectors of activity. Indeed, most of our sample is written as follows. $32.72 \%$ of the companies belong to the industry sector, $27.58 \%$ to the trade sector, $15.28 \%$ to the technology sector, $18.34 \%$ to the transport sector and finally the rest are firms that operate in the energy sector.

However, it seems crucial that before proceeding to test our selected econometric models, to present the descriptive statistics of the variables used: 
Table 3. Descriptive Statistics (Model 1)

\begin{tabular}{llll}
\hline Variable & Mean & Median & Std Dev \\
\hline INEW & 0.094 & 0.064 & 0.067 \\
Growth & 1.658 & 1.264 & 1.128 \\
Leverage & 0.284 & 0.263 & 0.163 \\
Cash & 0.091 & 0.028 & 0.108 \\
Age & 3.589 & 3.238 & 1.173 \\
Size & 7.291 & 7.341 & 1.257 \\
Stock Returns & 0.081 & 0.063 & 0.241 \\
\hline
\end{tabular}

First at all, an examination of the descriptive statistics reveals that US companies invest, on average, $9.4 \%$ of their assets. The liquidity level amounts, on average, to $9.1 \%$ of the total assets. All the more, we would like to mention that the average of short-term and long-term debt is equal to $28.4 \%$ of the total assets. Concerning the age of the firm, which is measured by the logarithm of the number of years since the date of its creation, it's equal on average to 3.5. From this table, we show also that firm's size is on average 7.2. These results reconcile the idea that American companies, which make up our sample, create a favorable ground for testing the sensitivity between investment and the different explanatory variables of the first model.

Table 4. Descriptive Statistics (Model 2 and 3)

\begin{tabular}{llll}
\hline Variable & Mean & Median & Std Dev \\
\hline $\mathrm{I}_{\mathrm{NEW}}^{\varepsilon}$ & 0 & -0.009 & 0.137 \\
FCF & 0.081 & 0.024 & 0.158 \\
EC & 0.081 & 0.063 & 0.241 \\
\hline
\end{tabular}

From the table, we find that the average over-investment is $0 \%$, while the median is $-0.009 \%$. This result, which is similar to Xiao \& Zhou (2017), seems to be a favorable ground for testing our research hypothesis. Indeed, it turns out that the American manager is always taking a step towards an investment level higher than the predicted one. Regarding the first independent variable, the manager's overconfidence, we notice that the average is 0.081 while the median is equal to 0.063 . In this respect, it seems that the manager has an overconfidence that can harm the rest of the stakeholders of the company. Finally, the second and last independent variable also shows attractive statistics regarding the level of free cash flows. US companies free cash flows are on average 0.081 of total assets, while the median is 0.024 . This latter result is also attractive because the presence of FCFs gives presumptions about the risk of over-investment.

\subsection{Measure of Overinvestment}

At this stage, it should be revealed that in order to measure over-investment expenditure, we will proceed by validating the two expected investment models, which are strongly inspired from those of Richardson (2006), Taghavi et al. (2014) and Chen et al. (2016). The parameters of the two models 1 and 2 are estimated according to the GMM system dynamic panel method, and more precisely the estimator of Blundell \& Bond (1998). The choice of this method is justified by the presence of a retarded endogenous variable $\mathrm{I}_{\mathrm{NEW}_{\mathrm{t}-1}}$. The regression results are presented in the following table:

Table 5. Expectations model investment

\begin{tabular}{|c|c|c|c|}
\hline Variable & Predicted sign & Model 1 & Model 2 \\
\hline Growth $_{\mathrm{t}-1}$ & - & & $\begin{array}{l}-0.019 * * * \\
(-11.76)\end{array}$ \\
\hline Leverage $_{t-1}$ & - & $\begin{array}{l}-0.068 * * * \\
(-8.93)\end{array}$ & $\begin{array}{l}-0.054 * * * * \\
(-6.47)\end{array}$ \\
\hline Cash $_{t-1}$ & + & $\begin{array}{l}0.115^{* * *} \\
(9.45)\end{array}$ & $\begin{array}{l}0.901 * * * \\
(9.60)\end{array}$ \\
\hline $\operatorname{Age}_{t-1}$ & - & $\begin{array}{l}-0.010 * * * \\
(-12.01)\end{array}$ & $\begin{array}{l}-0.009 * * * \\
(-13.37)\end{array}$ \\
\hline $\operatorname{Size}_{t-1}$ & + & $\begin{array}{l}0.007 * * * \\
(7.86)\end{array}$ & $\begin{array}{c}0.007 * * * \\
(9.23)\end{array}$ \\
\hline Stock Returns $_{\mathrm{t}-1}$ & + & $\begin{array}{l}0.015 * * * \\
(8.73)\end{array}$ & $\begin{array}{l}0.012 * * * \\
(9.58)\end{array}$ \\
\hline $\mathrm{I}_{\mathrm{NEWi}, \mathrm{t}-1}$ & + & $\begin{array}{l}0.471 * * * \\
(13.34)\end{array}$ & $\begin{array}{l}0.418 * * * \\
(11.79)\end{array}$ \\
\hline Wald chi2 & & 38.45 & 51.72 \\
\hline Prob> chi 2 & & 0.000 & 0.000 \\
\hline Hansen's statistic & & 7.16 & 12.33 \\
\hline Prob $>\mathbf{J}$ (Hansen) & & 1.00 & 1.00 \\
\hline AR(1) (Prob > $>$ ) & & 0.014 & 0.044 \\
\hline $\operatorname{AR}(2)(\operatorname{Prob}>z)$ & & 0.785 & 0.719 \\
\hline Observations & & 2700 & 2700 \\
\hline
\end{tabular}

$*$ indicates significant at the $10 \%$ level; $* *$ indicates significant at the $5 \%$ level; $* * *$ indicates significant at the $1 \%$ level. 
To start the empirical analysis, we begin by pointing out that unlike Richardson (2006) and Chen et al. (2016), who use the static fixed effects panel as an estimation method, we have questioned the dynamic panel method of the GMM system, which makes it possible to counter the problems of heteroscedasticities and autocorrelations. In both models, we find that the hypothesis $\mathrm{H}_{0}$ of the validity of the instruments is not rejected. Indeed, the probability of the Hansen statistic is greater than 5\%, which implies that the instruments are generally exogenous. Also, the probabilities of the Arellano and Bond test of AR (2) are greater than 5\%, which means that there is no second order serial autocorrelation. Regarding the overall significance of the model, it turns out that both models show a probability of the Wald test of 0.000 which is significantly lower than $5 \%$, which proves that they are globally significant.

Given these results, drawn from this last linear regression, it seems that the financial variables as well as those specific to the firm contribute significantly to determining the expected new investment expenditure. Expected new investment expenditure increases with cash flow, firm size (SIZE), stock returns and new investment expenditure of the previous year; and decrease with the age of the firm (Age) as well as its short term and long-term debt of the previous year (Leverage). Moreover, these results show that the introduction of the variable "growth opportunities" in model (1), could lead to an improvement in the explanatory power of the model. Indeed, the estimated coefficient of Growth variable is statistically significant at the $1 \%$ level in model (2). As a result, like Richardson (2006), we used the model (2) with the highest explanatory power to measure the new expected investment expenditure ( $\left.\mathrm{I}_{\mathrm{NEW}}^{*}\right)$.

\subsection{Relationship between Overinvestment and Free Cash Flows}

On the other hand, it is very pertinent to note that the main interest in estimating this last regression, is to determine a rigorous measure of the expected new investment expenditure ( $\left.\mathrm{I}_{\mathrm{NEW}}^{*}\right)$ and subsequently to deduce a measure of over-investment (INEW). Thus, like Richardson (2006) and very recently Chen, Sun \& Xu (2016) and Jiang (2016), our second step is to start a second regression that links over-investment with free cash flows. This regression seems to be a useful because it makes it possible to validate or reject our first hypothesis of research. The results are reported in the following table:

Table 6. Relation between over-investment and free cash flow

\begin{tabular}{cc}
\hline Variable & Model \\
\hline Constant & $0.010^{* * * *}$ \\
& $(3.87)$ \\
$\mathrm{FCF}<0$ & $0.154^{* * *}$ \\
& $(6.29)$ \\
$\mathrm{FCF}>0$ & $0.236^{* * *}$ \\
& $(8.64)$ \\
& 0.059 \\
R-squared & 5.67 \\
Fisher & 0.0000 \\
Prob $>\mathrm{F}$ & 2700 \\
\hline
\end{tabular}

FCF $<0$ equals the FCF for FCF values below zero and zero otherwise. FCF $>0$ equals the FCF for FCF values greater than zero and zero otherwise. * indicates significant at the $10 \%$ level; ** indicates significant at the $5 \%$ level; *** indicates significant at the $1 \%$ level.

The regression results reported in this table corroborate the acceptance of our first research hypothesis according to which firms with free cash flows are able to over-invest. Indeed, these results which coincide with those of Miguel \&Pindado (2001), Mcmahon (2003), Xuesong et al. (2007), Fu (2011), Tangjitprom (2015) and Guarglia\& Yang (2016), demonstrate and confirm that managers are opportunistic and builders of empires, an idea that was initiated by Jensen (1986). Moreover, given the regression estimation results for the entire sample, it seems that the coefficients are all statistically significant at a confidence level of $99 \%$. Even more, the results show that the estimated coefficient of $\delta_{1}$ is 0.154 , while that of $\delta_{2}$ is 0.236 . This suggests that firms with positive free cash flows are more likely to engage in over-investment than firms with negative free cash flows.

\subsection{Relationship between Overinvestment and Overconfidence}

In order to enrich our empirical tests, we used behavioral finance and more particularly, overconfidence as well as its possible effect on the over-investment of free cash flows. In this regard, Kramer \& Liao (2012) and Ahmed \&Duellman (2013) state that the overconfident manager overestimates the return on investment and therefore intends to delay recognition of losses. This leads this type of manager to consider negative NPV projects as positive NPV projects, which increases the risk of over-investment. This assent has been validated recently by Hribar\& Yang (2015), who show that overconfidence leads the manager to overestimate his future expectations. 
Thus, to test our second hypothesis, and unlike Richardson (2006) and Chen et al. (2009), we introduced an interaction variable between free cash flows and overconfidence. The results of our hypothesis, which states that over-investment increases with the overconfidence of the managers, are mentioned in the following table:

Table 7. Over-investment of free cash flows and manager's overconfidence

\begin{tabular}{ll}
\hline Variable & Model \\
\hline Constant & $0.004^{* *}$ \\
& $(2.13)$ \\
$\mathrm{FCF} * \mathrm{EC}<0$ & $0.257 * * *$ \\
$\mathrm{FCF} * \mathrm{EC}>0$ & $(14.17)$ \\
& $0.471^{* * *}$ \\
$\mathrm{R}-\mathrm{squared}$ & $(17.72)$ \\
Fisher & 0.062 \\
Prob $>$ F & 6.71 \\
Observations & 0.0000 \\
\hline
\end{tabular}

* indicates significant at the $10 \%$ level; ** indicates significant at the $5 \%$ level; *** indicates significant at the $1 \%$ level.

In the light of empirical evidence, it is consistent with our second research hypothesis that the manager's behavioral bias, which manifests itself by overconfidence, may exacerbate the over-investment problem of free cash flows. Investment decision is among many very important decisions managers must make, can be affected by managers' characteristics. Indeed, given this table, and in total concordance with the results of Ying, Xing \&Zhaonan (2005), Doukas\&Petmezas (2007), Ye\& Yuan (2008), Wang, Zhang \& Yu (2010), Grundy \& Li (2010), Chen \&Lin (2012, 2013), Ben Mouhamed, Fairchild \&Bouri (2014) and Wang et al. (2016), we note that highly confident managers with positive free cash flows tend to over-invest much more than those who are highly confident and have negative free cash flows. In fact, the coefficient of the combined variable $\left(\beta_{2}\right)$ is almost twice superior of the combined variable $\left(\beta_{1}\right)$. This result, like Barros \&Silveira (2008), demonstrates that excessively confident managers overestimate their abilities and thus place too much importance on their personal information or their point of view. Xiao \& Zhou (2017) reconcile this hypothesis and show that manager's overconfidence is not an essential ingredient of good investment decision-making. Rather, they show that excessive manager confidence combined with free cash flows amplify over-investment expenditure.

Also, to better understand the effect of overconfidence on the over-investment of free cash flows, we split our sample into two categories of managers according to their degree of confidence. A first category includes managers who are highly confident, while the second category includes those who are less confident.

Table 8. Over-investment of free cash flows and manager's overconfidence

\begin{tabular}{llll}
\hline Variable & Highly confident managers & Less confident managers & Wald F-statistic \\
\hline Constant & $0.005^{* *}$ & $0.132 * * *$ & \\
& $(1.98)$ & $(4.84)$ & $11.21^{* * * *}$ \\
FCF $<0$ & $0.243^{* * *}$ & $0.134^{* * *}$ & \\
& $(15.81)$ & $(11.14)$ & $9.21^{* * *}$ \\
FCF $>0$ & $0.452^{* * *}$ & $0.211^{* * *}$ & \\
& $(18.52)$ & $(14.49)$ & \\
R-squared & 0.067 & 0.043 & \\
Fisher & 7.21 & 5.34 & \\
Prob $>$ F & 0.0000 & 0.0000 & 1166 \\
Observations & 1534 & 1166 & \\
\hline
\end{tabular}

* indicates significant at the $10 \%$ level; $* *$ indicates significant at the $5 \%$ level; *** indicates significant at the $1 \%$ level.

From this last table, it should be established that the degree of overconfidence of managers is a variable that allows managing over-investment of free cash flows. All models combined, and in accordance with Zhu \& Tan (2010) and Lu \& Liu (2016), it turns out that excessively confident managers are more likely to embark on the over-investment of free cash flows. Moreover, these results bring us back to the idea that highly confident managers with negative free cash flows can over-invest. Indeed, we note that the coefficient associated with the variable $(F C F<0)$ is positive and statistically significant at the $1 \%$ level. Thus, as Huang, Jiang, Liu and Zhang (2011), it seems to be accepted that the manager's overconfidence, shows a psychological bias, which can mislead the investment decision and consequently destroy the performance of the firm. This last result has been confirmed by Heaton (2002), for whom excessive confidence, fueled at the same time by distinguished free cash flows, has led to the waste of free cash flows, which results in an increase in over-investment expenditure. 


\section{Conclusion}

The objective of this research is to examine the effect of behavioral finance, as measured by overconfidence, on the over-investment of free cash flows. More specifically, the positive relationship between over-investment expenditure and free cash flow, which is heavily debated in the financial literature, seems to have a behavioral explanation. More specifically, it seems to be the shimmering of the manager' overconfidence (Heaton, 2002; Wang et al., 2016).

At the end of our empirical study, covering 150 American companies during the period 1995-2012, it turns out that the sensitivity of over-investment to free cash flows is due to the assumption of managerial discretion. Also, we were able to show in accordance with Grundy \& Li (2010), Hribar\& Yang (2015) and Wang et al. (2016) that overconfident managers tend to over-invest much more than those who are less confident.

Lastly, the results obtained lead us to open horizons for a possible extension of this work in a later stage. Indeed, we suggest revising the approximations used to apprehend certain variables whose choice and measurement often pose problems. Indeed, some of the fundamental variables underlying the theoretical financial models on which our work is based are either unmeasurable or imperfectly measurable such as overconfidence. Also, it seems relevant and interesting to distinguish within the group of the companies composing our sample, the state-controlled public firms and the managerial firms. Despite the similarity of the shareholder-manager relationship in these two categories of firms, this does not hide divergences both in terms of the motivations of the managers and the control systems of the managers of these firms.

\section{References}

Ahmed, A. S., \& Duellman, S. (2013). Managerial overconfidence and accounting conservatism. Journal of Accounting Research, 51(1), 1-30. https://doi.org/10.1111/j.1475-679X.2012.00467.x

Barros, L., \& Silveira, A. (2008). Overconfidence, Managerial Optimism, and the Determinants of Capital Structure. Brazilian Review of Finance, 6(3), 293-335.

Bates, T. (2005). Asset sales, investment opportunities, and the use of proceeds, Journal of Finance, 60(1), 105-135. https://doi.org/10.1111/j.1540-6261.2005.00726.x

Ben Mohamed, E., Fairchild, R., \& Bouri, A. (2014). Investment cash flow sensitivity under managerial optimism: new evidence from NYSE panel data firms. Journal of Economics, Finance and Administrative Science, 19(36), 11-18. https://doi.org/10.1016/j.jefas.2014.04.001

Ben-David, I. T., Graham, J. R., \& Harvey, C. R. (2013). Managerial Miscalibration. The Quarterly Journal of Economics (2013), 1547-1584. https://doi.org/10.1093/qje/qjt023

Bergstresser, D. (2006). Discussion of Overinvestment of free cash flow. Review of accounting Studies, 11,191-202. https://doi.org/10.1007/s11142-006-9002-3

Blanchard, O., Lopez, S. F., \& Shleifer, A. (1994). What do firm with cash windfalls. Journal of financial economics, 36, 337-360. https://doi.org/10.1016/0304-405X(94)90009-4

Blundell, R., \& Bond, S. (1998). Initial conditions and moment restrictions in dynamic panel data models. Journal of Econometrics, 87(1), 115-143. https://doi.org/10.1016/S0304-4076(98)00009-8

Brown, R., \&Sarma, N. (2007). CEO overconfidence, CEO dominance and corporate acquisitions. Journal of Economics and Business, 59, 358-379. https://doi.org/10.1016/j.jeconbus.2007.04.002

Chen, B., Xu, L., \& Yu, H. (2009). Overinvestment when control separates from ownership. Working paper University of Southern California, Electronic copy available at: https://doi.org/10.2139/ssrn.1376829

Chen, I. J., \& Lin, S. H. (2012). Will managerial optimism affect the investment efficiency of a firm? Procedia Economics and Finance, 2, 73-80. https://doi.org/10.1016/S2212-5671(12)00066-4

Chen, I. J., \& Lin, S. H. (2013). Managerial Optimism, Investment Efficiency, and Firm Valuation. Multinational Finance Journal, 17(3/4), 295-340. https://doi.org/10.17578/17-3/4-6

Chen, S., \& Liao, Z. (2012). Free Cash Flow and Over-investment: the Moderating Role of the Characteristics of Independent Director. Advances in information Sciences and Service Sciences, 4(3), 147-158. https://doi.org/10.4156/aiss.vol4.issue3.19

Chen, X., Sun, Y., \& Xu, X. (2016). Free cash flow, over-investment and corporate governance in China. Pacific-Basin Finance Journal, 37, 81-103. https://doi.org/10.1016/j.pacfin.2015.06.003 
Doukas, J. A., \& Petmezas, D. (2007). Acquisitions, Overconfident Managers and Self-attribution Bias. Europpen Financial Management, 13(3), 531-577.https://doi.org/10.1111/j.1468-036X.2007.00371.x

Fu, F. (2011).Overinvestment and the Operating Performance of SEO Firms. Financial Management, 39(1), 249-272. https://doi.org/10.1111/j.1755-053X.2010.01072.x

Grundy, B. D., \& Li, H. (2010). Investor sentiment, executive compensation, and corporate investment. Journal of Banking \& Finance, 34(10), 2439-2449. https://doi.org/10.1016/j.jbankfin.2010.03.020

Guariglia, A., \& Yang J. (2016). A balancing act: Managing financial constraints and agency costs to minimize investment inefficiency in the Chinese market. Journal of Corporate Finance, 36, 111-130. https://doi.org/10.1016/j.jcorpfin.2015.10.006

Hayward, M., \&Hambrick, D. (1997). Explaining the premiums paid for large acquisitions: Evidence of CEO hubris. Administrative Science Quarterly, 42,103-127. https://doi.org/10.2307/2393810

Heaton J. (2002). Managerial optimism and corporate finance. Financial Management, 31, 33-45. https://doi.org/10.2307/3666221

Hirshleifer, D. A., Teoh, S. H., \& Low, A. (2012). Are Overconfident CEOs Better Innovators? The Journal of Finance, 67, 1457-1498. https://doi.org/10.1111/j.1540-6261.2012.01753.x

Hribar, P., \& Yang, H. (2015). CEO overconfidence and management forecasting. Contemporary Accounting Research, 33(1), 204-227. https://doi.org/10.1111/1911-3846.12144

Huang, W., Jiang, F., Liu, Z., \& Zhang, M. (2011). Agency cost, top executives' overconfidence, and investment-cash flow sensitivity: Evidence from listed companies in China. Pacific-Basin Finance Journal, 19,261-277. https://doi.org/10.1016/j.pacfin.2010.12.001

Jensen, M. C. (1986). Agency costs of free cash flow, corporate finance and takeovers. American Economic Review, 76, 323-339.

Jiang, X. (2016). Over-Investment of Free Cash Flow during CEO's Tenure. Technology and Investment, 7, 51-58. https://doi.org/10.4236/ti.2016.73007

Kallapur, S. (1994). Dividend payout ratios as determinants of earnings response coefficients. Journal of Accounting Economics, 17, 359-375. https://doi.org/10.1016/0165-4101(94)90033-7

Kramer, L. A., \& Liao, C. M. (2012). The Cost of False Bravado: Management overconfidence and Its Impact on Analysts' Views. 25th Australasian Finance and Banking Conference. Available at SSRN: https://ssrn.com/abstract=2128128 or https://doi.org/10.2139/ssrn.2128128

Lin, Y. H., Hu, S. Y., \& Chen, M. S. (2005). Managerial optimism and corporate investment: Some empirical evidence from Taiwan. Pacific-Basin Finance Journal, 13, 523-546. https://doi.org/10.1016/j.pacfin.2004.12.003

Lu, W., \& Liu, H. (2016). The empirical study on the relation between managerial overconfidence and over-investment. Published in: Service Systems and Service Management (ICSSSM), 2016, 13th International Conference.

Malmendier, U., \& Tate, G. (2005). CEO overconfidence and corporate investment. Journal of Finance, 60(6), 2661-2700. https://doi.org/10.1111/j.1540-6261.2005.00813.x

Malmendier, U., \& Tate, G. (2008). Who makes acquisitions? CEO overconfidence and the market's reaction. Journal of Financial Economics, 89(1), 20-43. https://doi.org/10.1016/j.jfineco.2007.07.002

Mcmahon, R. (2003). An exploratory study of under and over-investment amongst manufacturing SMEs from Australia's business longitudinal survey. International Small Business Journal, 21(1), 29-53. https://doi.org/10.1177/0266242603021001720

Miguel, A., Pindado, J. (2001). Determinants of capital structure: New evidence from Spanish panel date. Journal of Corporate Finance, 1, 77-99. https://doi.org/10.1016/S0929-1199(00)00020-1

Mueller, D. C., \& Peev, E. (2007). Corporate governance and investment in Central and Eastern Europe. Journal of Comparative Economics, 35, 414-437. https://doi.org/10.1016/j.jce.2007.02.001

Richardson, S. (2006). Over-investment of free cash flow. Review of Accounting Studies, 10(45-76), 89.https://doi.org/10.1007/s11142-006-9012-1

Roll, R. (1986). The hubris hypothesis of corporate takeovers. Journal of Business, 59, 197-216. 
https://doi.org/10.1086/296325

Taghavi, M., Valahzaghardb, M. K., \& Amirjahadic, N. (2014) .An investigation on the effect of the corporation governance structure and free cash flow on over-investment. Management Science Letters, 4, 567-572. https://doi.org/10.5267/j.msl.2014.1.007

Tang, X. S., Zhou, X. S., \& Ma, R. J. (2007). Empirical research on over-investment behavior and its restriction systems in China's listed Companies. Accounting Research, 7, 44-52.

Tangjitprom, N. (2015). Over-investment and Free Cash Flow: Evidence from Thailand. International Conference on Business, Economics and Management (ICBEM'15) April 9-10, Phuket (Thailand).

Wang, X., Zhang, M., \& Yu, F. (2010). Managerial overconfidence and over-investment: Empirical evidence from China. Frontiers of Business Research in China, 3, 453-469. https://doi.org/10.1007/s11782-009-0022-2

Wang, Y., Chen, C. R., Chen, L., \& Huang, Y. S. (2016). Overinvestment, inflation uncertainty, and managerial overconfidence: Firm level analysis of Chinese corporations. The North American Journal of Economics and Finance, 38, 54-69. https://doi.org/10.1016/j.najef.2016.07.001

Xiao, L., \& Zhou, A. (2017). The Impact of Managers Overconfidence on Corporate Investment. International Journal of Social Science and Humanity, 7(2), 109-114. https://doi.org/10.18178/ijssh.2017.V7.804

Ye, B., \& Yuan, J. (2008). Firm value, managerial confidence, and investments: Evidence from Chinese listed companies. Journal of Leadership Studies, 2(3), 26-36.https://doi.org/10.1002/j1s.20072

Ying, H., Xing, L., \& Zhaonan, L. (2005). China's Listed Companies Overconfidence and Investment Decision empirical study. Journal of Management Science, 10(5), 101-112.

Yong, L., Dao, G. S., \& Haiyue, L. (2015). An Empirical Study on Institutional Investors, Free Cash Flow and Over-investments. Journal of Business and Economics, 6(8), 1414-1421. https://doi.org/10.15341/jbe(2155-7950)/08.06.2015/002

Zhang, D. Z., Cao, H., Dickinson, D. G., \& Kutan, A. M. (2016). Free cash flows and overinvestment: Further evidence from Chinese energy firms. Energy Economics, 58, 116-124. https://doi.org/10.1016/j.eneco.2016.06.018

Zhang, G. F. (2007). Is a Firm's Free Cash Flow to Be Overinvested?-Evidence from China Listed Companies. Economics and Management Research, 6, 11-16.

Zhu, L., \& Tan, B. (2010). Managerial overconfidence and corporate overinvestment. Published in: Information Management and Engineering (ICIME), 2010 The 2nd IEEE International Conference. https://doi.org/10.1109/ICIME.2010.5477755

\section{Copyrights}

Copyright for this article is retained by the author(s), with first publication rights granted to the journal.

This is an open-access article distributed under the terms and conditions of the Creative Commons Attribution license (http://creativecommons.org/licenses/by/4.0/). 